\section{Journal of Structural Biology}

www.elsevier.com/locate/yjsbi

\title{
Otolith crystals (in Carapidae): Growth and habit
}

\author{
Eric Parmentier ${ }^{\mathrm{a}, *}$, Rudi Cloots ${ }^{\mathrm{b}}$, Roger Warin ${ }^{\mathrm{b}}$, Catherine Henrist ${ }^{\mathrm{b}}$ \\ a Laboratoire de Morphologie Fonctionnelle et Evolutive, Institut de chimie, Bât. B6C, Université de Liège, B-4000 Liège, Belgium \\ ${ }^{\mathrm{b}}$ CAT $\mu$ and Chimie des Matériaux inorganiques, Institut de chimie, Bât. B6C, Université de Liège, B-4000 Liège, Belgium
}

Received 27 February 2007; received in revised form 21 May 2007; accepted 25 May 2007

Available online 12 June 2007

\begin{abstract}
The biomineralization of otoliths results mainly from the release of soluble $\mathrm{Ca}^{2+}$, which is in turn precipitated as $\mathrm{CaCO}_{3}$ crystals. In some Carapidae, sagittae sections have been shown to reveal a three-dimensional asymmetry with a nucleus close to the sulcal side, an unusual position. This study seeks to understand otolith formation in Carapus boraborensis. The unusual shape of the otolith is partly explained by the distribution of the epithelium cells, and particularly the sensory epithelium. Experimental evidence shows for the first time that aragonite growth takes place along the $c$-axis. These aragonite needles present two different habits. On the sulcal side is found the acicular form resulting from rapid growth during a short period of time. On the anti-sulcal side, the prismatic form seen there is due to a slower growth speed over longer periods. The otolith surface was observed each hour during a period of $24 \mathrm{~h}$ in fishes reared in similar conditions. This allowed for the first time the direct observation on the otolith surface of the deposition of the two layers (L-zone and D-zone). In C. boraborensis, the organic-rich layer (D-zone) develops during the day, whereas the $\mathrm{CaCO}_{3}$ layer ( $\mathrm{L}$-zone) seems to be deposited during the night.
\end{abstract}

(c) 2007 Elsevier Inc. All rights reserved.

Keywords: Otolith; Carapidae; Aragonite; Habit; Crystal; Daily cycle

\section{Introduction}

The major roles associated with the otoliths of the inner ear in teleosts are sound transduction and participation in maintaining static and dynamic equilibrium (Lowenstein, 1971; Tavolga, 1971; Platt and Popper, 1981; Schuijf, 1981; Popper, 1982; Gauldie, 1988). Like all functional structures in an organism, the stato-acoustic system must consequently have a shape and organization that represent a compromise between different needs and functions such as swimming, hearing, equilibration, etc. (Parmentier et al., 2001). The otolith consists of a predominant mineral phase of $\mathrm{CaCO}_{3}$ (Carlström, 1963) enmeshed into an organic matrix consisting of a complex network of macromolecules with $\mathrm{Ca}^{2+}$-binding functions (Wright et al., 2002; Borelli et al., 2003). Crystals commonly occur in the aragonite form of calcium carbonate and the orientation of the

\footnotetext{
${ }^{*}$ Corresponding author. Fax: +320 03665024.

E-mail address: E.Parmentier@ulg.ac.be (E. Parmentier).
}

crystal facets is sometimes referred to as being twinned (Degens et al., 1969; Gauldie and Nelson, 1988). Other forms, such as calcite and vaterite, occur as partial or total replacements of aragonite in some otoliths, but such otoliths are uncommon (Carlström, 1963; Gauldie, 1993, 1999). The predominance of aragonite (orthorhombic) on the calcite (rhombohedral) is unclear since the two polymorphs have very similar crystal structures, differing in the organization of the carbonate molecule sandwiched between layers of calcium ions (Campana, 1999; Falini et al., 2005). Small quantities of ions, such as $\mathrm{Sr}$ and $\mathrm{Mg}$, could favor the formation of aragonite over calcite (Carlström, 1963).

Otolith growth consists of daily deposition of a double deposit of a layer rich in minerals and a layer rich in organic material (Pannella, 1971), resulting in alternating translucent and opaque concentric rings (Campana and Neilson, 1985). Biomineralization of otoliths differs from that of vertebrate bone, molluscan shell and coral skeleton, since the otolith epithelium is not in direct contact with the 
region of calcification (Campana, 1999). As a result, the calcification is strongly dependent upon the chemical composition of the endolymphatic fluid (Falini et al., 2005), which has an alkaline $\mathrm{pH}$ and contains all the ionic precursors (e.g. high $\mathrm{K}^{+}$and saturated $\mathrm{Ca}^{2+}$ and $\mathrm{HCO}_{3}{ }^{-}$concentrations), proteins, collagen and amino acids for otolith formation (Campana, 1999; Borelli et al., 2001; Payan et al., 2002).

The endolymphatic fluid is secreted by the saccular epithelium, which is composed of many cell types arranged in two zones: (1) A proximal zone, bathing the proximal face of the otolith and composed of the macula (sensory cells, supporting cells and secretory cells), and a crown of large ionocytes (mitochondriarich cells), arranged in a meshwork around the macula; (2) On the opposite side, a distal zone bathing the distal side of the otolith is composed of squamous cells and small ionocytes (Mayer-Gostan et al., 1997; Takagi, 1997; Pisam et al., 1998; Takagi, 2000a,b). The different cellular zones seem to be at the origin of a lack of uniformity in the spatial distribution of ionic and organic endolymphatic components in the endolymph, and could be involved in the acellular process of otolith formation (Payan et al., 1999; Borelli et al., 2003). The formation seems to result from the release of soluble $\mathrm{Ca}^{2+}$ on the proximal side, which is in turn precipitated as $\mathrm{CaCO}_{3}$ crystals due to an increasing alkaline gradient (Mugiya, 1974; Gauldie and Nelson, 1990). This process has been corroborated by recent studies dealing with the various cellular types of the saccular epithelium (Mayer-Gostan et al., 1997; Pisam et al., 1998). In some species, variation in distribution within this epithelium of cellular ionic pumps (Mayer-Gostan et al., 1997; Toshe and Mugiya, 2001) and of secretory cells (Payan et al., 1999) has led to a solute gradient, the formation of which has been shown to interfere with otolith bio-calcification by favoring deposition on the proximal side or on the otolith edge (Payan et al., 1999; Takagi and Takahashi, 1999; Takagi, 2000b). Moreover, soluble proteins (= otolin) with a high abundance of acidic amino acids (Davis et al., 1997; Murayama et al., 2002) could control calcium carbonate morphology and polymorphism (Söllner et al., 2003), favoring aragonite over calcite (Falini et al., 1996).

As a result of otolith formation, sagittal otoliths are generally described as medially convex and distally concave bodies with a centrally located nucleus, or, more often, with one positioned closer to the anti-sulcal side (Dunkelberger et al., 1980; Gauldie and Nelson, 1990). However, in carapids, sagittal sections have revealed a three-dimensional asymmetry with a nucleus close to the sulcal side (Parmentier et al., 2002), resulting from a differential accretion rate. The Carapus sp. fish (Carapidae) are small, eellike fishes that are able to penetrate and stay inside different invertebrate hosts such as echinoderms (sea cucumber, starfish) or bivalves. Carapus species are commensal, and use their host as a shelter (Parmentier and Das, 2004).

Generally speaking, this study seeks to understand the unusual position of the nucleus in Carapus boraborensis
(Carapidae). This fish is used because its nucleus asymmetry could confirm or deny the existing models on otolith formation. Three different approaches were undertaken in order to understand more deeply otolith growth and organization in carapids: (1) a study of cell distribution in the endolymphatic epithelium surrounding the sagitta; (2) electron back-scattering diffraction (EBSD) and (3) scanning electron microscopy (SEM) were used to examine the fundamental crystal structure of the otolith, as well as the orientation and crystallographic relationships of the mineral.

\section{Materials and methods}

Sixty-four specimens of Carapus boraborensis (total length: 13-32 cm) were collected in Opanohu Bay, Moorea (French Polynesia). They were found inside specimens of Bohadschia argus and Thelenota ananas, at depths ranging from 1 to $20 \mathrm{~m}$. The fish were divided into four groups. Fishes from the first three groups were directly deeply anesthetized with MS222 before they were (1) stored in a 75\% ethanol solution $(n=21)$, (2) frozen at $-20{ }^{\circ} \mathrm{C}(n=10)$ and (3) fixed in Bouin for the production of serial histological sections $(n=3)$. Fishes from the fourth group $(n=30)$ were placed in an aquarium $(120 \times 40 \times 20 \mathrm{~cm})$ filled with running seawater, under natural lighting conditions (13L:11D). Every $60 \mathrm{~min}$, during a period of $24 \mathrm{~h}$, one fish from this group was removed from the tank and was anesthetized with MS222. The two sagittae were then removed and placed in absolute ethanol or in acetone.

Otolith sagittae of groups 1, 2 and 4 were used for observations. Each otolith was dehydrated in an oven and was coated by Au-Pd pulverization (Balzers SCD-30). The gold sputtering is realized in such conditions to obtain a gold layer $<10 \mathrm{~nm}(30 \mathrm{~s}, 30 \mathrm{~mA}$, argon plasma, distance $50 \mathrm{~mm}$ ). The signal of $\mathrm{Au}$ in the EDX spectra is weak enough to allow significant detection of light elements.

Photographs were taken with a scanning electron microscope (JEOL, JSM-840) under a $19 \mathrm{kV}$ acceleration voltage or with an Environmental Scanning Electron Microscope (Philips ESEM XL30) equipped with a Field Emission Gun under a $19 \mathrm{kV}$ acceleration voltage. The EDX spectra of the spherule otoliths were collected on a square area of $1 \mu \mathrm{m} \times 1 \mu \mathrm{m}$ centred in the middle of the spherule.

Sections of three sagittae were prepared by mounting each otolith on a glass slide in thermoplastic cement (Crystal Bond). Frontal and transverse sections of sagittae were obtained by grinding the piece with wet sand paper of decreasing grit sizes (600, 800 and 1200 grit) and polishing them with wet $0.3 \mu \mathrm{m}$ grit paper. Polished otoliths were observed with a TSL MSC-2200 (EBSD) camera coupled with ESEM (under a $25 \mathrm{kV}$ acceleration voltage), allowing the carrying out of an Electron Back-Scattering Diffraction (EBSD) study. This technique is used to draw up the cartography of the crystallographic orientation of monoand polycrystalline materials in otoliths.

After Bouin fixation, heads of $C$. boraborensis were decalcified in 3\% nitric acid and neutralized in $5 \% \mathrm{Na}_{2} \mathrm{SO}_{4}$. 
The pieces were then dehydrated in butanol, embedded in paraffin and serial cut with a Reichert microtome $(8-\mu \mathrm{m}$ thick). Sagittal, frontal and cross-sections were stained using Masson's trichrome method. Histological sections were observed with a Leica DM 1000 binocular microscope coupled with a Canon PowerShot S50 camera.

\section{Results}

A detailed description of the otic cavity bones and of the otolith shape already exists in the literature (Parmentier et al., 2001, 2002). Here are reported the morphological features that complete these descriptions.

\subsection{Endolymphatic epithelium}

The saccular epithelium is composed of the sensory, transitional and squamous epithelia. (1) The sensory epithelium is medial and consists of high prismatic hair cells $( \pm 25 \mu \mathrm{m})$, which were lined with supporting cells. This otosac zone shows a high number of blood vessels and nerve endings. At this level, the gelatinous layer fixes the otolith to the sensory epithelium. (2) The meshwork/transitional epithelium borders the macula and is made of smaller (5$7 \mu \mathrm{m})$ and cuboidal cells. This zone becomes still thinner and forms the (3) squamous epithelium. This is situated on the opposite side of the macula and consists of small flattened cells $(>2.5 \mu \mathrm{m})$. Small blood vessels are also situated next to this zone.

Comparisons of the heights of the different parts of the otolith sulcal side and of the epithelium layers show that the sensory epithelium area corresponds to the colliculum (Fig. 1B). Moreover, the zone facing the important bulge of the sagitta is also the zone where blood vessels are the most developed. The otolith zones around both crista face the meshwork/transitional epithelium. The latter is particularly well developed at the level of the anterior part of the otolith, whereas this is not the case further back where the otolith is thinner. The squamous epithelium faces the antisulcal side of the otolith.

\subsection{Morphology of aragonite crystals}

In Carapus boraborensis, the sagitta has the shape of a semi-convex lens (Fig. 2A1). The distal face of the otolith seems to form two distinct parts. The anterior part of the sagitta looks like a half-sphere, whereas the posterior part shows a long post-rostrum with a pointed end (Fig. 2A1). The proximal face displays an elliptical sulcus occupied by a single colliculum lined dorsally by the crista superior and ventrally by the crista inferior (Fig. 2B1). Sections in the sagitta show clearly the asymmetrical location of the nucleus, which is closer to the sulcal side (Fig. 3A). In sectioned otoliths, the nucleus seems to be placed on a line delimiting the wide anti-sulcal side and the narrow sulcal side (Fig. 3A). The aragonite needles radiate from the nucleus. On the anti-sulcal side, the radiation gives rectilinear needles whose progressive lateral slanting confers to the sphere a tiered appearance (Fig. 2A2 and A3). At the level of the distal dome, only the distal end of the needles is visible at the surface of the otolith (Figs. 2A2 and 3C). As a result of the slanting, the needles lean more and more posteriorly (Fig. 2A3) and finally appear in a horizontal plane at the level of the post-rostrum (Fig. 2A4). At this level, it is possible to see the lateral faces of the needles and to discern easily the alternate deposition of protein and crystal

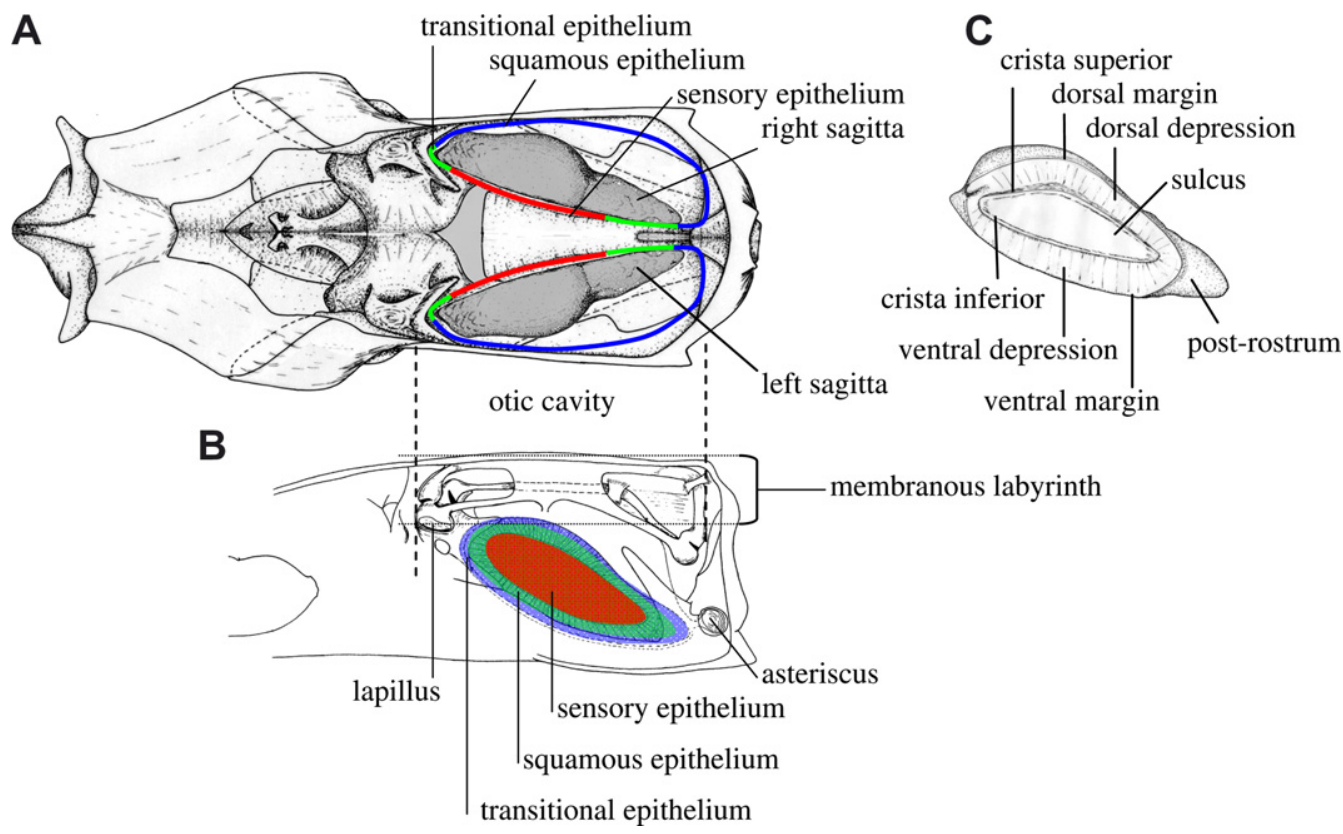

Fig. 1. Schematic dorsal (A) and lateral (B) view of the otic cavity and of the otosac epithelium in Carapus boraborensis; modified from Parmentier et al. (2001). Lateral (sulcal or proximal side) view of the right C. boraborensis sagitta (C). 

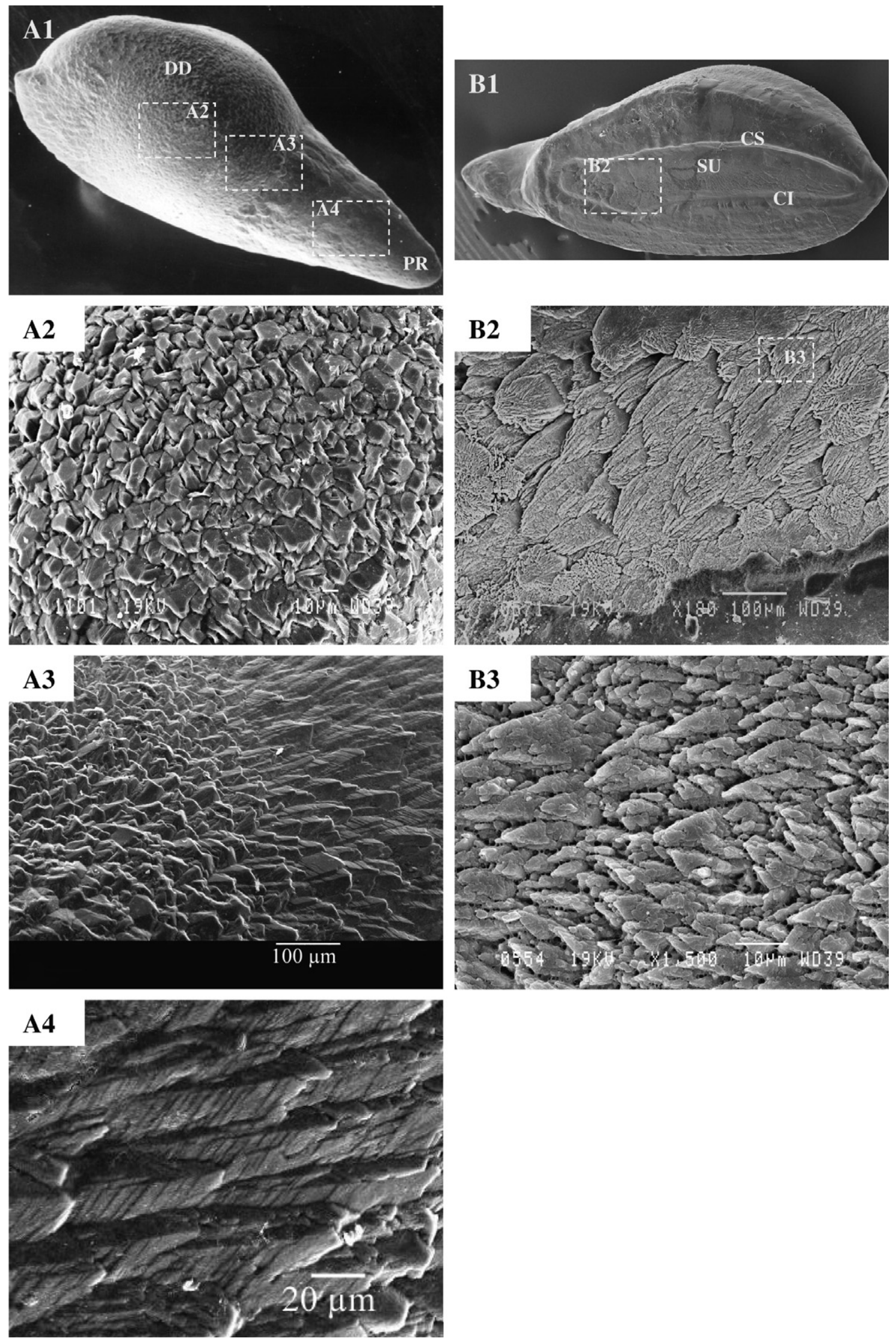

Fig. 2. Lateral view of the left Carapus boraborensis sagitta. A1: sulcal (or proximal) side and B1: anti-sulcal (or distal) side. Annotated squares in A are enlarged in either A2, A3 or A4, showing the progressive lateral slanting from the dorsal dome (DD) to the post-rostrum (PR). B2 is an enlarged view of the square in B1, and B3 is an enlarged view of the square in B2. CI: crista inferior; CS: crista superior; SU: sulcus. 

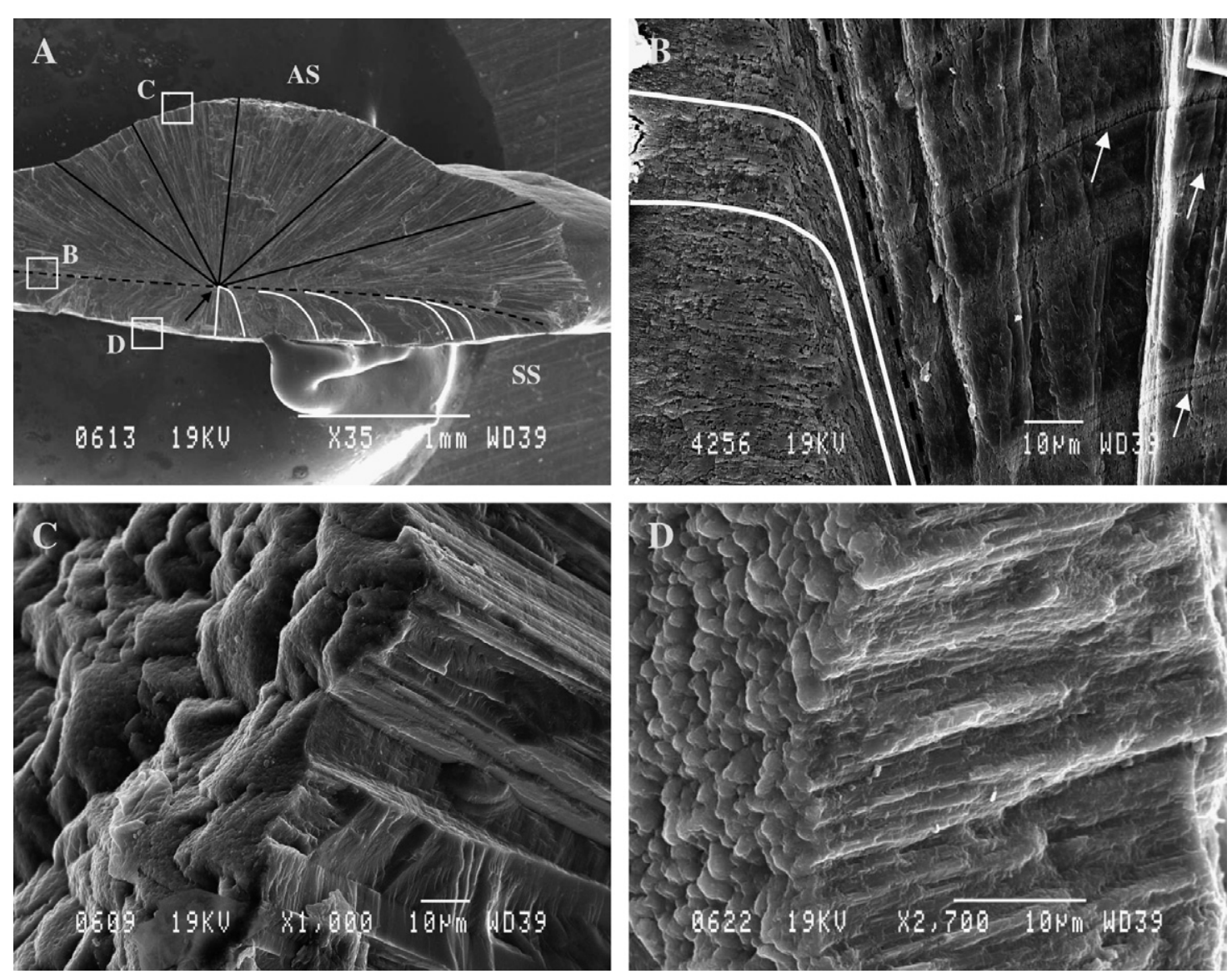

Fig. 3. A: sagittal section in the Carapus boraborensis sagitta. B-D: enlarging of the respective squares in A. Black and white lines: orientation of the needles toward the distal and proximal side, respectively; dotted line: white arrow: organic layer; black arrow: nucleus. AS: anti-sulcus side; SS: sulcus side.

layers (Fig. 2A4). The habitus of the distal region looks like an elongated prismatic form ending in an angular dome (Fig. 4A).

On the proximal face (Fig. 2B1), needles also come from the nucleus. However, the needles are not rectilinear and they present modification in their orientations (Fig. 3A and B). They are first parallel to the plane of the proximal face (= sulcal side) before presenting a modification of the orientation and they emerge perpendicularly to the sulcal side (Fig. 3A and B). These needles also appear thinner and it is difficult to see the protein increments (Fig. 3B). On the proximal face, the crystal habitus of the colliculum presents an acicular form (Fig. 4B), and the needles form groups oriented in different directions (Fig. 2B2 and B3).

The EBSD method was used to investigate the tridimensional crystal orientations and relationships of the mineral. The EBSD confirms the SEM analysis: the method allows the observation of the radial orientation of the crystal needles from the nucleus. On the color-coded map, each color corresponds to one of the aragonite axes pointing outwards in the direction of the viewer: $a, b$ or $c$ (Fig. 5). The distribution of green and blue zones in the figure indicates that both $a$ - and $b$-axes are perpendicular to the section. The absence of red pixels indicates that this $c$-axis is in the plane of the section. The same observations were made in the frontal and sagittal planes. These results indicate that the growth of the aragonite needles always follows the $c$-axis. Moreover, these observations are reinforced by the 3D analysis of the aragonite mapping. The $c$-axis (highlighted in pink on the corresponding unit cells) always lies parallel to the growth direction of the needles, whereas both $a$ - and $b$-axes present random orientations (Fig. 5). However, both axes do not adopt any preferred orientation relative to the needles direction. This is translated by a random distribution of green and blue color from a crystal to another. In a single needle, $a$ - or $b$-axis stays fixed from the nuclei throughout the whole growth as it is shown trough continuous blue or green needles from the nucleus to the surface (Fig. 5). Each needle can be considered as an aragonite single crystal.

\subsection{Otolith growth}

The otolith surface was observed over a period of $24 \mathrm{~h}$ in fishes reared in similar conditions. In Fig. 6, all pictures display the same scale and present the same otolith region: the dorsal dome. Crystal modifications were recorded at 7 a.m.; these result from the appearance of filamentous structures, which are attributed to organic matter. These filaments grow in number and thickness until 7 p.m., giving to the whole surface a net-like structure. From 10 p.m., these fibrilar structures seem to disappear progressively 
A
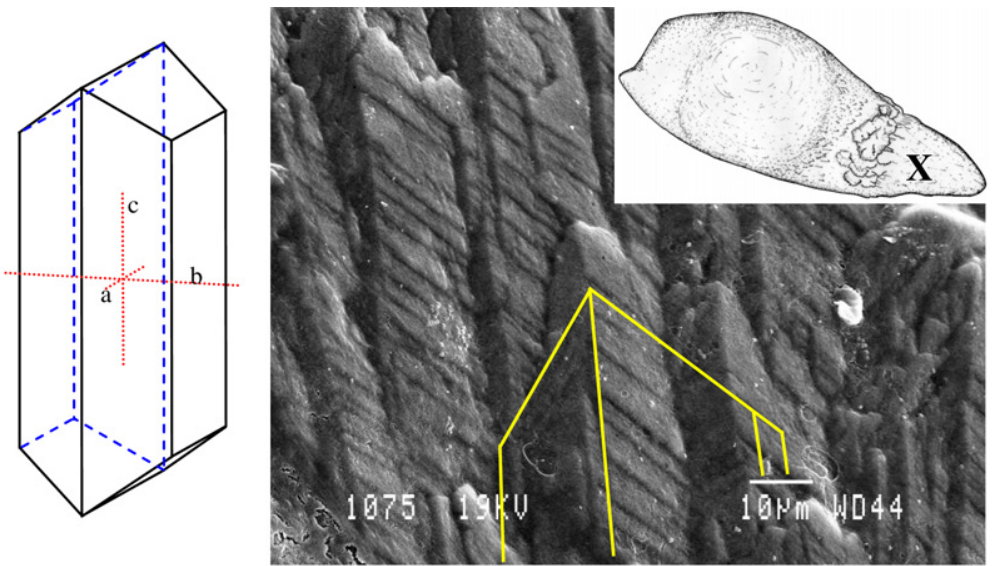

B
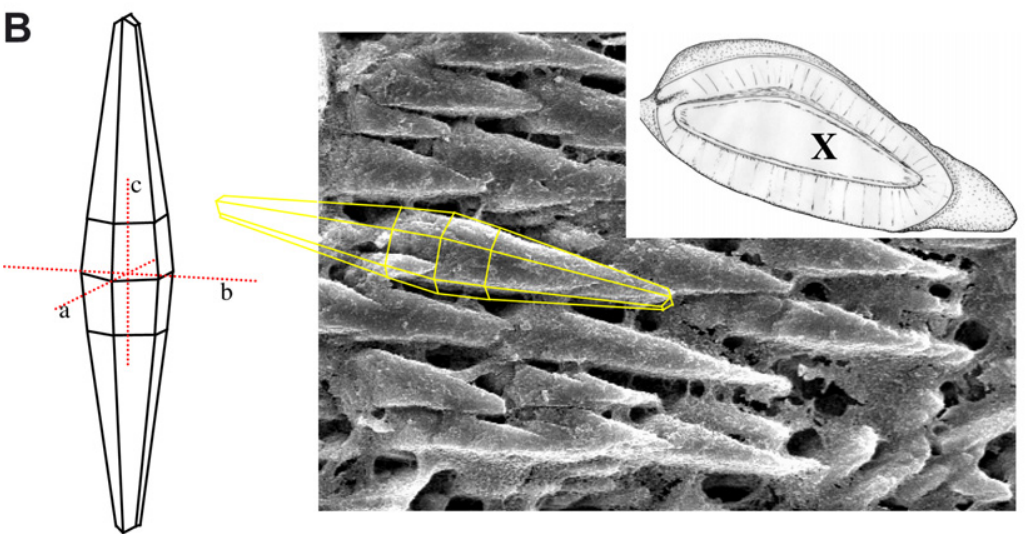

Fig. 4. Aragonite habits found on the distal side (A) and on the proximal side (B) in the sagitta of Carapus boraborensis. X: localization of the habits. Red dotted line: Miller index: $a=001, b=010, c=110$.

(Fig. 6). These observations lead us to suppose that the formation and the deposit of the organic matrix occur during the day.

Moreover, different small spherules were found on the otolith surface (Fig. 7). They appear larger (diameter average: $3.76 \mu \mathrm{m} \pm 0.1, n=20$ ) at the level of the sulcal side (Fig. 7A) than on the anti-sulcal side (diameter average: $440 \mathrm{~nm} \pm 0.1, n=13, p<0.0001$, Fig. 7B). Each spherule seems to be made of numerous subunits lengthening between 20 and $200 \mathrm{~nm}$. The external aspect is not constant. It can be globular or more and more "spread" onto the otolith surface. Behind these more or less complete spherules, it is possible to discern the otolith crystal (Fig. 7A). In order to characterize these different forms, the element composition was semi-quantitatively measured. The globular spherules are rich in carbon and in calcium, with a very high carbon content (Fig. 8A). By contrast, the "spread" forms have a proportionally higher calcium content to carbon ratio (Fig. 8C). Analysis of intermediate forms showed there was a progressive modification in the relative element content in relation to the spherule forms. The important amounts of carbon and calcium lead us to suppose that the spherules could be composed of one (or more) protein(s). Once deposited on the otolith surface, the degradation of the spherulitic protein complex or its conformation change could lead to the lib- eration of calcium, whereas the molecule seems resolubilised in the otosac, involving the diminution of the relative amount of carbon. Moreover, because the anti-sulcal side only possesses the subunits, it is supposed that there is a migration from the proximal side to the distal side.

\section{Discussion}

In generalized otolith models, the sagitta otoliths (Fig. 9) are described as medially convex and distally concave bodies with a centrally located nucleus, or, more often, with one positioned closer to the anti-sulcal side (Dunkelberger et al., 1980; Gauldie and Nelson, 1990; Parmentier et al., 2002). Both shape and nucleus location result from the release of soluble $\mathrm{Ca}^{2+}$ on the proximal side (Ibsch et al., 2004), which in turn precipitates as $\mathrm{CaCO}_{3}$ crystals due to an increasing alkaline gradient, from the sulcal area towards the otolith edge (Mugiya, 1974; Gauldie and Nelson, 1990). As a result, the growth of the crista superior and crista inferior is privileged and there is a more important development of the sulcal side. Moreover, the incorporation of the calcium at the level of the edges involves a decrease in the $\mathrm{Ca}^{2+}$ concentration and a weaker development of the distal side. This process has been corroborated by recent studies dealing with the various 


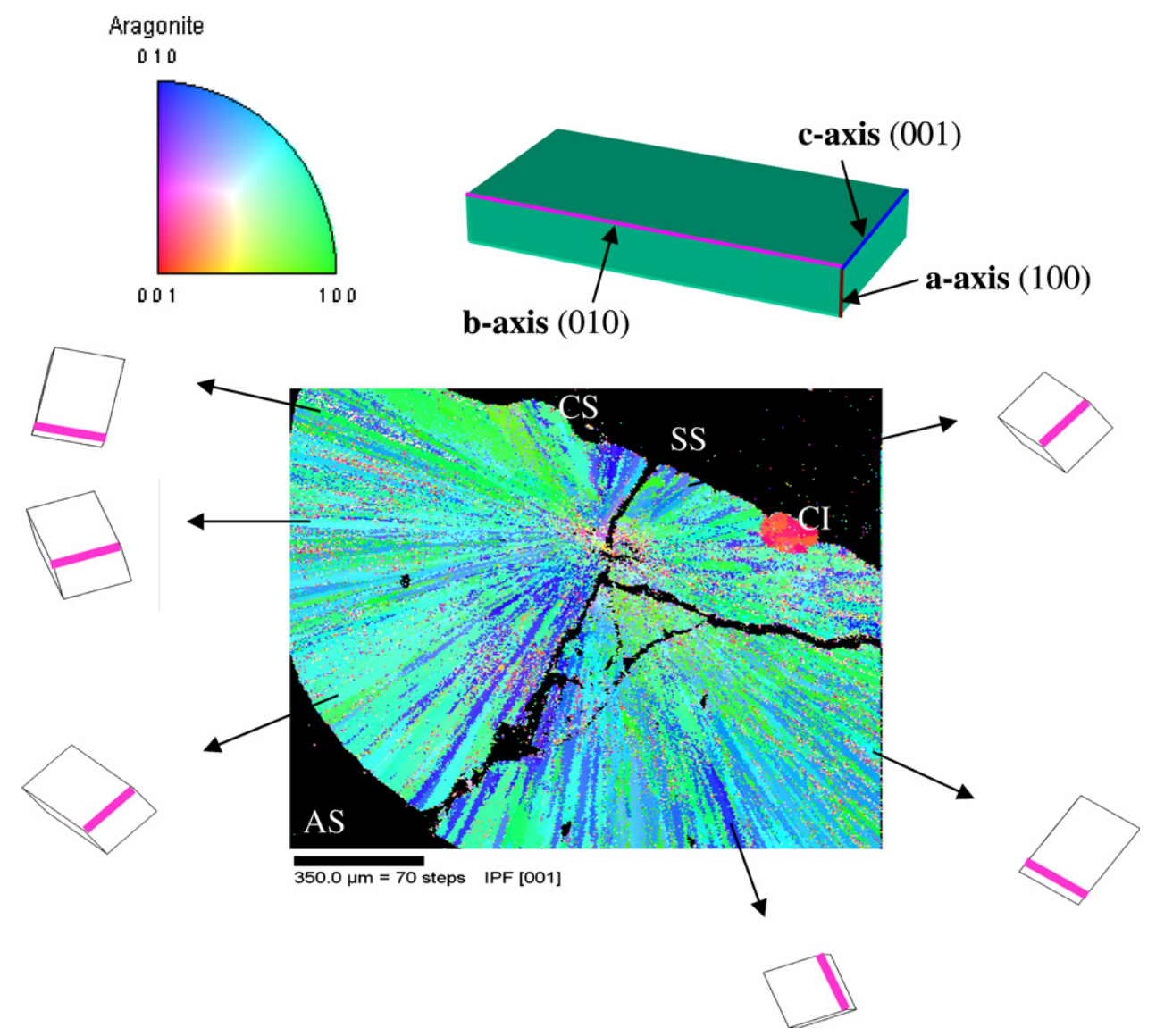

Fig. 5. Cartography of the aragonite crystals showing the orientation of the different axes $(a, b$ or $c)$ in Carapus boraborensis. The absence of red color in the radiated needles indicates that the $c$-axis (001) is perpendicular to the plane section. AS: anti-sulcus side; CI: crista inferior; CS: crista superior; SS: sulcus side.

cellular types of the saccular epithelium (Mayer-Gostan et al., 1997; Takagi, 1997, 2000a,b; Pisam et al., 1998), which were shown to be responsible for the establishment of a proximo-distal gradient favoring the $\mathrm{CaCO}_{3}$ deposit on the sulcal side (Payan et al., 1999, 2004). In Carapidae, the saccular epithelium presents the typical zones found in different teleosts (Pisam et al., 1998; Takagi, 1997, 2000a, 2002), indicating that the different zones should have the same properties.

Generally speaking, the macula is elongated and narrow in teleosts (Fig. 9), and the crista superior and inferior are proportionally more important than the colliculum (Popper and Hoxter, 1981; Lombarte and Fortuno, 1992; Ladich and Popper, 2001). The macula faces the colliculum, and prevents otolith growth at this level (Pannella, 1980; Popper and Hoxter, 1981; Lombarte and Fortuno, 1992). The colliculum is proportionally higher in the Carapidae, occupying a larger surface on the sulcal face (Fig. 9). This morphological trait indicates that the macula is particularly developed (see also Fig. 1). As a result, the sensory epithelium should prevent a high level of $\mathrm{CaCO}_{3}$ deposit on the height of the sulcal side and the crystal has to be deposited on the opposite side of the otolith, forming the important distal dome. Moreover, the dorsal depression being smaller than the ventral depression, the $\mathrm{CaCO}_{3}$ is more important dorsally, giving a dorsal position to the dome (Fig. 9). The size of the macula implies that the increasing alkaline gradient does not develop onto the height and length of the otosac but on its width. This study shows that the unusual shape of the otolith, and mainly the unusual position of the nucleus, results from differences in the proportion of the epithelial layers with a particularly well developed sensory epithelium. This does not contradict the usual model used to explain otolith formation (Payan et al., 2004).

\subsection{Crystal study}

The radial growth of aragonite needles in the otolith has already been described in numerous sagittae (e.g. Campana and Neilson, 1985; Lecomte-Finiger, 1992; Falini et al., 2005). The growth axis has already been highlighted in different abiotic and biotic environments: reptilian eggshells (Silyn-Roberts and Sharp, 1985), mollusk shells (Giles et al., 1995; Checa et al., 2006). However, growth along the $c$-axis is, to our knowledge, reported for the first time in otoliths.

Different habits of the same crystal in the otolith have already been demonstrated (Watabe, 1981; Gauldie, 1993), but remain poorly studied. The habit of the crystal depends on numerous factors such as growth speed, tem- 

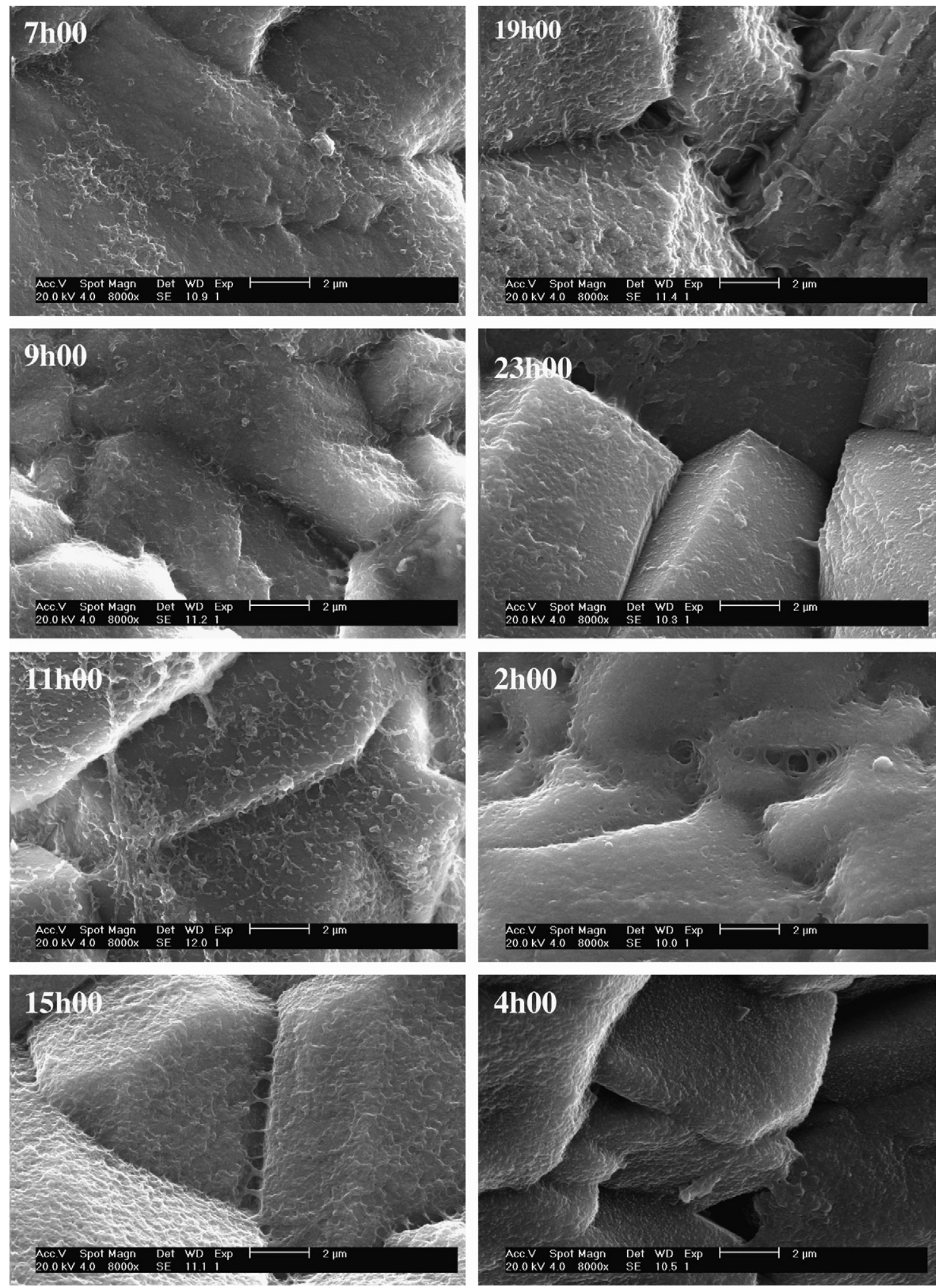

Fig. 6. Modification of the anti-sulcal surface of Carapus boraborensis during a period of $24 \mathrm{~h}$.

perature, viscosity of the medium and the presence of impurities that could prevent growth in some directions (Li et al., 1991). Growth control can be effective at two levels. (1) The thermodynamic level indicates that the presence of aragonite in otoliths is due to the presence of proteic pre- cursors (Borelli et al., 2003; Guibbolini et al., 2006). Calcium carbonate crystallizes into three different polymorphs: calcite, aragonite and vaterite. Experimental evidence from calcium carbonate overgrowth on the surface of otoliths has suggested that the intracrystalline 

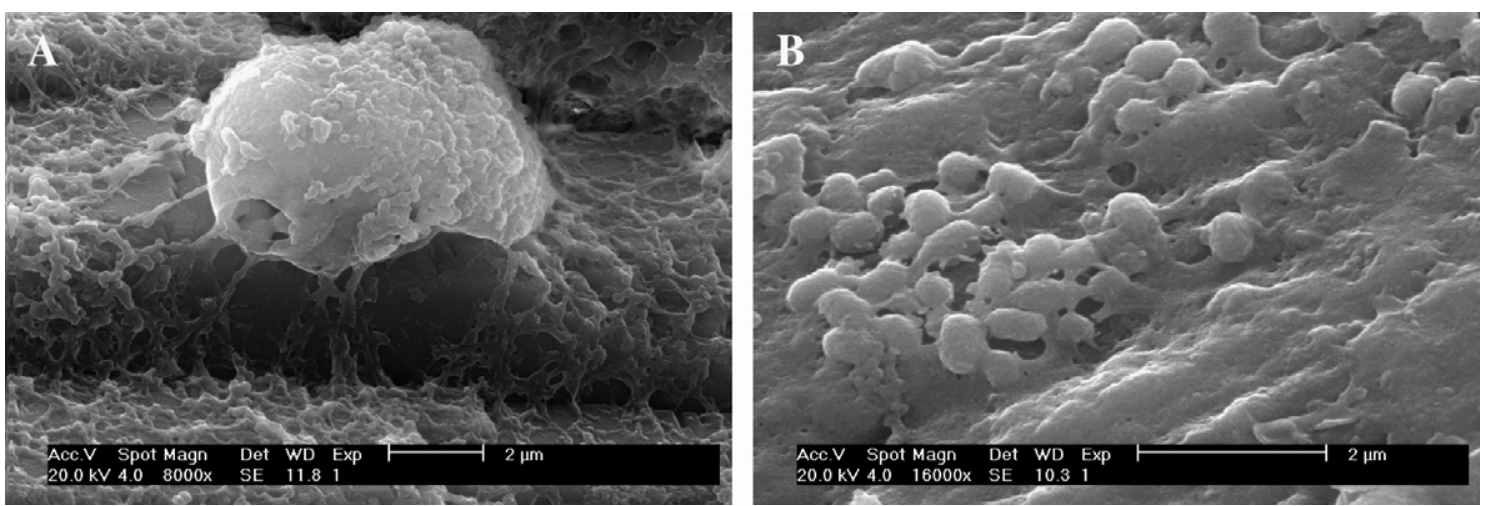

Fig. 7. Spherules found on the proximal (A) and distal (B) sides in the sagitta of Carapus boraborensis.
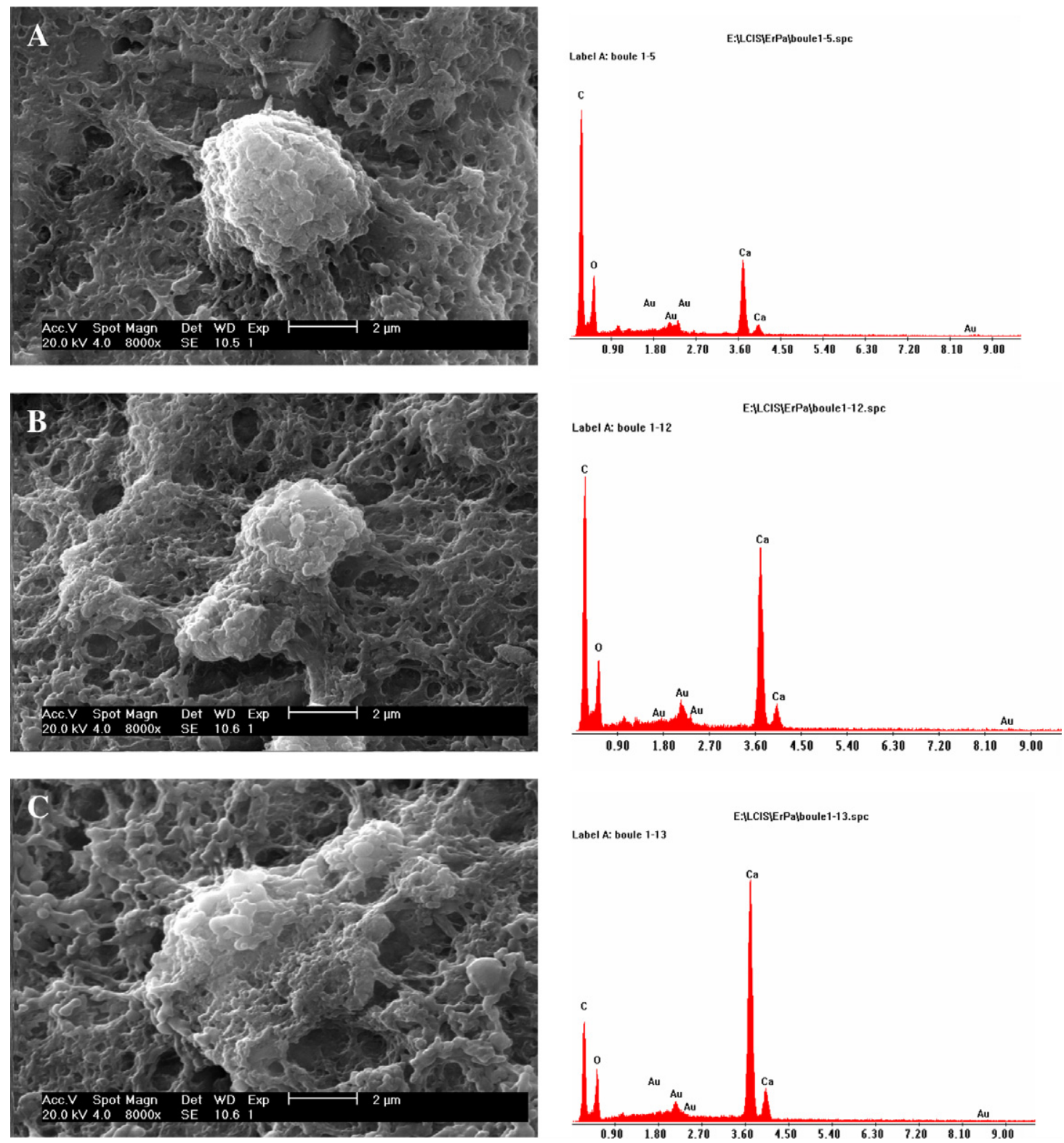

Fig. 8. Spherules of different shapes and sizes on the otolith surface in Carapus boraborensis. Flattening and spreading of the spherules onto the otolith surface in Carapus boraborensis, viewed by SEM, and corresponding modification of elemental composition determined by EDX. The progressive diminution of the spherules corresponds to a relative modification in the ration $\mathrm{Ca}$ : $\mathrm{C}$. 


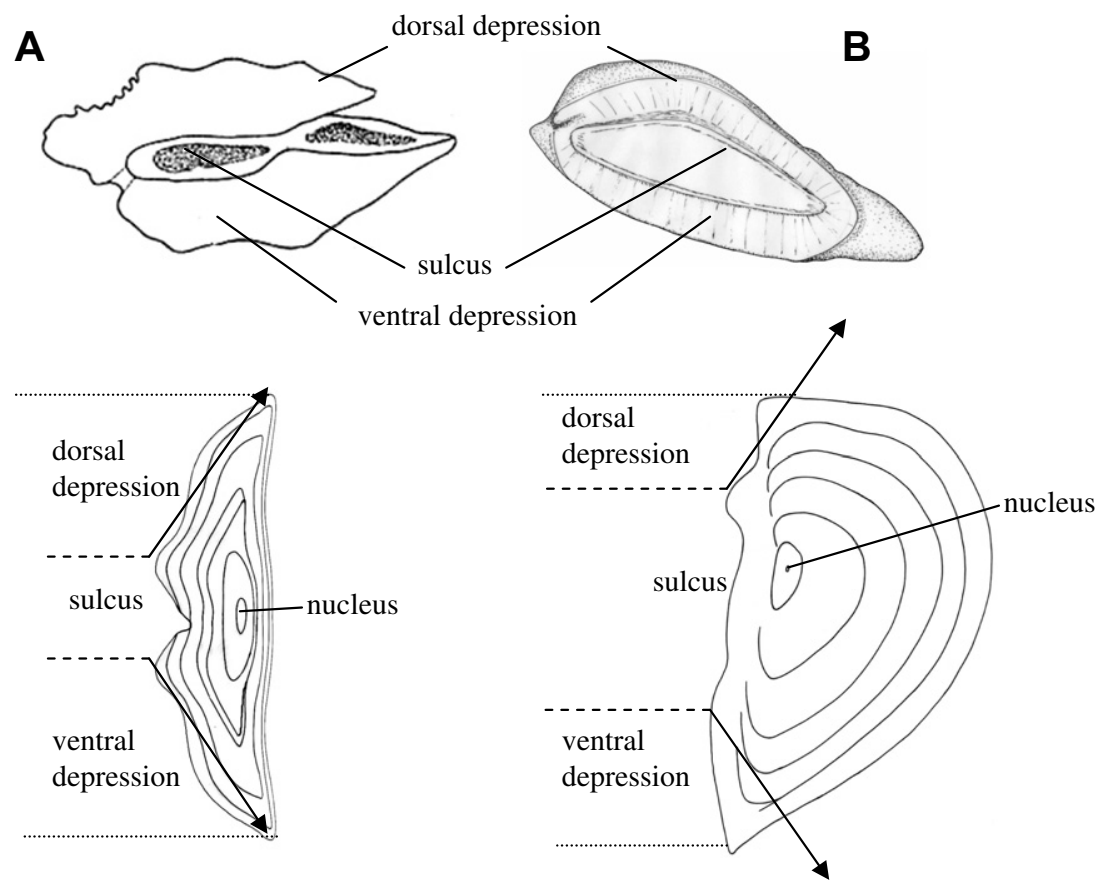

Fig. 9. Comparison of a "generalized" otolith model of Teleostean (A) with a carapid otolith (B). 1: sulcal side; 2: schematic view of a transverse section.

macromolecules associated to the otolith favor aragonite polymorphism (Falini et al., 2005). (2) The kinetic level could be responsible for the habit type. This depends on physico-chemical factors such as the lack of uniformity in the chemical composition of the saccular endolymph (Payan et al., 1999). Moreover, the adsorption of different ions can stimulate or inhibit the growth of different faces.

This study reports the presence of (at least) two different habits in the $C$. boraborensis sagitta. The first, the prismatic form, is found on the anti-sulcal side and the second, the acicular form, on the sulcal side. These two types of habit could result from different environmental conditions. On the sulcal side, the ionic concentration is important (Payan et al., 1999) and could be at the origin of a rapid growth during a short period of time. On the anti-sulcal side, the ionic concentration is lower (Payan et al., 1999), leading to lower growth speed but over longer periods. However, the idea cannot be excluded that habit type is partly determined by matrix proteins.

\subsection{Circadian cycle}

The alternate deposit of organic and mineral layers seems dependent on the photoperiod (Tanaka et al., 1981; Radtke and Dean, 1982; Mugiya, 1984, 1987). There are few studies dealing with the circadian cycle of layer deposition. In the Oncorhynchus mykiss trout, the bilayer rings of otolith growth during the day:night cycle correspond to anti-phasic mechanisms: organic matrix deposition starts at the end of the day, whereas $\mathrm{CaCO}_{3}$ deposition starts at the beginning of the day (Borelli et al., 2003). On the other hand, Edeyer et al. (2000) found that, in the Psetta maxima turbot, the incremental zone (L-zone) was formed at night, whereas the discontinuous zone (D-zone) was formed during the daytime. In both cases, these circadian variations were deduced from the ionic composition and protein concentration in the plasma and endolymph.

For the first time, the deposition of the two layers (Lzone and D-zone) has been observed here directly on the otolith surface. In C. boraborensis, the organic-rich layer develops during the day, whereas the $\mathrm{CaCO}_{3}$ layer seems to be deposited during the night, the small spherules giving a globular appearance to the otolith surface. It was also observed that spherules on the proximal side are bigger than on the distal side. These bigger spherules appear to be made of smaller particles that were found only on the distal side, suggesting the degradation of the large spherules and the migrations of the particles. In Oreochromis mossambicus, discrete calcium carbonate precipitations were also more numerous in the proximal endolymph than in the distal endolymph, clearly indicating a decreasing proximo-distal gradient and that the calcium supply of the otoliths takes place via the proximal endolymph (Ibsch et al., 2004).

Orchestration of extracellular calcification requires bringing together ionic and proteinaceous components in time and space. Local alkaline microenvironments in the endolymph are required to promote the precipitation of the calcium carbonate (Mugiya et al., 1981; Payan et al., 1997). It has been accepted that the organic matrix, mainly composed of proteins such as glycoproteins, collagens, proteoglycans and $\mathrm{Ca}^{2+}$ binding proteins, was essential in the calcification process (Murayama et al. 2005, Guibbolini et al., 2006) and in the control of the calcium carbonate morphology and polymorphism (Falini et al., 2005). 
Flattening and spreading of the spherules onto the otolith surface in Carapus boraborensis seems correspond to the $\mathrm{CaCO}_{3}$ precipitation, and the resolubilisation of macromolecules.

\section{Acknowledgments}

We thank C. Brié (Tropical Fish Tahiti, Rangiroa), Y. Chancerelle (CRIOBE, Moorea, French Polynesia) and their respective team for helping to obtain living carapids. N. Decloux kindly helped in the microscopic study. This study was supported by Grant C-05/77 from "Fonds spéciaux, Université de Liège".

\section{References}

Borelli, G., Mayer-Gostan, N., De Pontual, H., Bœuf, G., Payan, P., 2001. Biochemical relationships between endolymph and otolith matrix in the trout (Oncorhynchus mykiss) and turbot (Psetta maxima). Calcif. Tissue Int. 69, 356-364.

Borelli, G., Guibbolini, M.E., Mayer-Gostan, N., Priouzeau, F., De Pontual, H., Allemand, D., Puverel, S., Tambutte, E., Payan, P., 2003. Daily variations of endolymph composition: relationship with the otolith calcification process in trout. J. Exp. Biol. 206, 2685-2692.

Carlström, D., 1963. A crystallographic study of vertebrate otoliths. Biol. Bull., Woods Hole 125, 441-463.

Campana, S.E., 1999. Chemistry and composition of fish otoliths: pathways, mechanisms and applications. Mar. Ecol. Prog. Ser. 188, 263-297.

Campana, S.E., Neilson, J.D., 1985. Microstructure of fish otoliths. Can. J. Fish Aquatic Sci. 42, 1014-1031.

Checa, A.G., Okamoto, T., Ramırez, J., 2006. Organization pattern of nacre in Pteriidae (Bivalvia: Mollusca) explained by crystal competition. Proc. R. Soc. B 273, 1329-1337.

Davis, J.G., Burns, F.R., Navaratnam, D., Masaji Lee, A., Ichimiya, S., Oberholtzer, J.C., Greene, M.I., 1997. Identification of a structural constituent and one possible site of postembryonic formation of a teleost otolithic membrane. Proc. Natl. Acad. Sci. 94, 707-712.

Degens, E.T., Deuser, W.G., Haedrich, R.L., 1969. Molecular structure and composition of fish otoliths. Mar. Biol. 2, 105-113.

Dunkelberger, D.G., Dean, J.M., Watabe, N., 1980. The ultrastructure of the otolithic membrane and otolith in the juvenile mummichog, Fundulus heteroclitus. J. Morph. 163, 367-377.

Edeyer, A., De Pontual, H., Payan, P., Troadec, H., Severe, A., MayerGostan, N., 2000. Daily variations of saccular endolymph and plasma compositions in the turbot Psetta maxima: relationship with the diurnal rhythm in otolith formation. Mar. Ecol. Prog. Ser. 198, 287-294.

Falini, G., Albeck, S., Weiner, S., Addadi, L., 1996. Control of aragonite or calcite polymorphism by mollusc shell macromolecules. Science 271, 67-69.

Falini, G., Fermani, S., Vanzo, S., Miletic, M., Zaffino, G., 2005. Influence on the formation of aragonite or vaterite by otolith macromolecules. Eur. J. Inorg. Chem. 1, 162-167.

Gauldie, R.W., 1988. Function, form and time-keeping properties of fish otoliths. Comp. Biochem. Physiol. A 91, 395-402.

Gauldie, R.W., Nelson, D.G.A., 1988. Aragonite twinning and neuroprotein secretion are the cause of daily growth rings in fish otoliths. Comp. Biochem. Physiol. A 90, 501-509.

Gauldie, R.W., Nelson, D.G.A., 1990. Otolith Growth in fishes. Comp. Biochem. Physiol. A 97, 119-135.

Gauldie, R.W., 1993. Polymorphic crystalline structure of fish otoliths. J. Morphol. 218, 1-28.

Gauldie, R.W., 1999. Ultrastructure of lamellae, mineral and matrix components of fish otolith twinned aragonite crystals: implications for estimating age in fish. Tissue Cell 31, 138-153.
Giles, R., Manne, S., Mann, S., Morse, S.E., Stucky, G.D., Hansma, P.K., 1995. Inorganic overgrowth of aragonite on molluscan nacre examined by atomic force microscopy. Biol. Bull. 188, 8-15.

Guibbolini, M., Borelli, G., Mayer-Gostan, N., Priouzeau, F., De Pontual, H., Allemand, D., Payan, P., 2006. Characterization and variations of organic parameters in teleost fish endolymph during daynight cycle, starvation and stress conditions. Comp. Biochem. Physiol. A $145,99-107$.

Ibsch, M., Anken, R.H., Rahmann, H., 2004. Calcium gradients in the fish inner ear sensory epithelium and otolithic membrane visualized by energy filtering transmission electron microscopy (EFTEM). Adv. Sp. Res. 33, 1395-1400.

Ladich, F., Popper, A.N., 2001. Comparison of the inner ear ultrastructure between teleost fishes using different channels for communication. Hear. Res 154, 62-72.

Lecomte-Finiger, R., 1992. Growth history and age at recruitment of European glass eels (Anguilla anguilla) as revealed by otolith microstructure. Mar. Biol. 144, 205-210.

Li, Y., Stein, M., Jungnickel, B.J., 1991. Competition between crystallisation and phase separation in polymers blends. Diffusion controlled supermolecular structure and phase morphologies in poly (e-caprolactone) (polystyrene blends). Colloid. Polym. Sci. 269, $772-780$.

Lombarte, A., Fortuno, J.M., 1992. Differences in morphological features of the sacculus of the inner ear of two hakes (Merluccius capensis and M. paradoxus, Gadiformes) inhabits from different depth of sea. J. Morph. 214, 97-107.

Lowenstein, O., 1971. The labyrinth. In: Hoar, W.S., Randall, D.J. (Eds.), Fish Physiology, vol. 5. Academic Press, New York, pp. 207-240.

Mayer-Gostan, N., Kossmann, H., Watrin, A., Payan, P., Bøuf, G., 1997. Distribution of ionocytes in the saccular epithelium of the inner ear of two teleosts (Oncorhynchus mykiss and Scophthalmus maximus). Cell Tissue Res. 289, 53-61.

Mugiya, Y., 1974. Calcium-45 behavior at the level of the otolith organs of rainbow trout. Bull. Jpn. Soc. Sci. Fish. 40, 457-463.

Mugiya, Y., 1984. Diurnal rhythm in otolith formation in the rainbow trout, Salmo gairdeni: seasonal reversal of the rhythm in relation to plasma calcium concentrations. Comp. Biochem. Physiol A 78, 289-293.

Mugiya, Y., 1987. Phase difference between calcification and organic matrix formation in the diurnal growth of otoliths in the rainbow trout, Salmo gairdeneri. Comp. Biochem. Physiol. A 84, 57-60.

Mugiya, Y., Watabe, N., Yamada, J., Dean, J.M., Dunkelberger, D.G., Sjimizu, M., 1981. Diurnal rhythm in otolith formation in the goldfish (Carassius auratus). Comp. Biochem. Physiol. 68A, 659-662.

Murayama, E., Takagi, Y., Ohira, T., Davis, J.G., Greene, M.I., Nagasawa, H., 2002. Fish otolith contains a unique structural protein, otolin-1. Eur. J. Biochem. 269, 688-696.

Murayama, E., Herbomel, P., Kawakami, A., Takeda, H., Nagasawa, H., 2005. Otolith matrix proteins OMP-1 and Otolin-1 are necessary for normal otolith growth and their correct anchoring onto the sensory maculae. Mech. Dev. 122, 791-803.

Pannella, G., 1971. Fish otoliths: daily growth layers and periodical patterns. Science 173, 1124-1127.

Pannella, G., 1980. Growth pattern of fish sagittae. In: Rhoad, D.C., Lutz, R.A. (Eds.), Skeletal Growth of Aquatic Organisms: Biological Records of Environmental Change, Topics in geobiology, vol. 1. Plenum Press, New York, pp. 519-560.

Parmentier, E., Vandewalle, P., Lagardère, F., 2001. Morpho-anatomy of the otic region in carapid fishes: eco-morphological study of their otoliths. J. Fish Biol. 58, 1046-1061.

Parmentier, E., Lagardère, F., Vandewalle, P., 2002. Relationships between inner ear and sagitta growth during ontogenesis of three Carapini species and consequences of life-history events on the otolith microstructure. Mar. Biol. 141, 491-501.

Parmentier, E., Das, K., 2004. Commensal vs parasitic relationship between Carapini fish and their host: some further insight through $\left({ }^{13} \mathrm{C}\right.$ and $\left({ }^{15} \mathrm{~N}\right.$ measurements. J. Exp. Mar. Biol. Ecol. 310, 47-58. 
Payan, P., Kossman, H., Watrin, A., Mayer-Gostan, N., Boeuf, G., 1997. Ionic composition of endolymph in teleosts: origin and importance of endolymph alkalinity. J. Exp. Biol. 200, 1905-1912.

Payan, P., Edeyer, A., de Pontual, H., Borelli, G., Bøuf, G., MayerGostan, N., 1999. Chemical composition of saccular endolymph and otolith in fish inner ear: lack of spatial uniformity. Am. J. Physiol. 277, 123-131.

Payan, P., Borelli, G., Priouzeau, F., De Pontual, H., Bœuf, G., MayerGostan, N., 2002. Otolith growth in trout Onchorynchus mykiss: supply of $\mathrm{Ca}^{2+}$ and $\mathrm{Sr}^{2+}$ to the saccular endolymph. J. Exp. Biol. 205, 2687-2695.

Payan, P., De Pontual, H., Bœuf, G., Mayer-Gostan, N., 2004. Endolymph chemistry and otolith growth in fish. C.R. Palevol. 3, 535-547.

Pisam, M., Payan, P., LeMoal, C., Edeyer, A., Bœuf, G., Mayer-Gostan, N., 1998. Ultrastructural study of the saccular epithelium of the inner ear of two teleosts, Oncorhynchus mykiss and Scophthalmus maximus. Cell Tissue Res. 294, 261-270.

Platt, C., Popper, A.N., 1981. Fine structure and function of the ear. In: Tavolga, W.N., Popper, A.N., Fay, R.R. (Eds.), Hearing and Sound Communication in Fishes. Springer-Verlag, New York, pp. 2-37.

Popper, A.N., 1982. Organization of the inner ear and auditory processing. In: Northcutt, E.G., Davis, R.E. (Eds.), Fish Neurobiology, vol. 1. The University of Michigan Press, Ann Arbor, pp. 126-178.

Popper, A.N., Hoxter, B., 1981. The fine structure of the sacculus and lagena of a teleost fish. Hear. Res. 5, 245-263.

Radtke, R.L., Dean, J., 1982. Increment formation in the embyos, larvae and juveniles of the mummichog, Fundulus heteroclictus. Fish. Bull. U.S. 80, 41-55.

Schuijf, A., 1981. Models of acoustic localization. In: Tavolga, W.N., Popper, A.N., Fay, R.R. (Eds.), Hearing and Sound Communication in Fishes. Springer-Verlag, New York, pp. 267-310.

Söllner, C., Burghammer, M., Busch-Nentwich, E., Berger, J., Schwarz, H., Riekel, C., Nicolson, T., 2003. Control of crystal size and lattice formation by starmaker in otolith biomineralization. Science 302 , $282-286$.
Silyn-Roberts, H., Sharp, R.M., 1985. Preferred orientation of calcite and aragonite in the reptilian eggshells. Proc. R. Soc. London B 225, 445455 .

Takagi, Y., 1997. Meshwork arrangement of mitochondria-rich, $\mathrm{Na}^{+}$, $\mathrm{K}^{+}$-ATPase-rich celles in the saccular epithelium of rainbouw trout (Onchorryhnchus mykiss) inner ear. Anat. Rec. 248, 483489.

Takagi, Y., 2000a. Cellular contributions to the otolith formation in teleosts: a review. Otsuchi Mar. Sci. 25, 1-6.

Takagi, Y., 2000b. Ultrastructural immunolocalization of the otolith water-soluble-matrix in the inner ear of rainbow trout just-hatched fry. Fish. Sci. 66, 71-77.

Takagi, Y., 2002. Otolith formation and endolymph chemistry: a strong correlation between the aragonite saturation state and $\mathrm{pH}$ in the endolymph of the trout otolith organ. Mar. Ecol. Prog. Ser. 231, 237245 .

Takagi, Y., Takahashi, A., 1999. Characterization of otolith soluble-matrix producing cells in the saccular epithelium of rainbow trout (Oncorhynchus mykiss) inner ear. Anat. Rec. 254, 322-329.

Tanaka, K., Mugiya, Y., Yamada, J., 1981. Effects of photoperiod and feeding on daily growth patterns in otoliths of juvenile Tilapia nilotica. Fish. Bull. 79, 459-466.

Tavolga, W.N., 1971. Sound production and detection. In: Hoar, W.S., Randall, D.J. (Eds.), Fish Physiology, vol. 5. Academic Press, New York, pp. 135-205.

Toshe, H., Mugiya, Y., 2001. Effects of enzyme and anion transport inhibitors on in vitro incorporation of inorganic carbon and calcium into endolymph and otoliths in salmon Oncorhyncus masou. Comp. Biochem. Physiol. 128A, 177-184.

Watabe, N., 1981. Crystal growth of calcium carbonate in the invertebrates. Prog. Cryst. Growth Charact. 4, 99-147.

Wright, P.J., Panfili, J., Morales-Nin, B., Geffen, A.J., 2002. Différents types de pièce calcifiée, In: Panfili, J., Pontual, H.D.E., Troadec, H., Wright, P.J. (Eds.), Manuel de sclérochronologie des poissons. Coédition Ifremer - IRD, pp. 31-88. 